\title{
PENERAPAN TEKNOLOGI TEPAT GUNA DALAM MENGOLAH LIMBAH JAGUNG
}

\author{
Rahmaniah $^{1 *}$, Muh. Khalifah ${ }^{1}$, Hafsan $^{3}$ \\ ${ }^{1}$ Jurusan Fisika Fakultas Sains dan Teknologi \\ ${ }^{2}$ Jurusan Pendidikan Biologi Fakultas Tarbiyah dan Keguruan \\ ${ }^{3}$ Jurusan Biologi Fakultas Sains dan Teknologi \\ Universitas Islam Negeri (UIN) Alauddin Makassar \\ *email: nia.physics08.uin@gmail.com
}

\begin{abstract}
Abstrak: Telah dilakukan penelitian tentang pemanfaatan limbah tanaman jagung (kulit dan tongkol jagung) sebagia bahan baku pembuatan papan akustik, pakan ternak dan briket. Selanjutnya ketiga jenis produk yang telah dihasilkan tersebut diaplikasikan dalam bentuk kegiatan pengabdian kepada masyarakat dengan tema penerapan teknologi tepat guna dalam mengolah limbah jagung. Kegiatan ini dilakukan pondok pesantrena Nahdhalul Ulum Kabupaten Maros dengan sasaran kegiatan adalah para santri di pondok pesantren tersebut. Tujuan Kegiatan ini untuk: 1) Memberikan pemahaman kepada santri untuk melestarikan lingkungan terutama untuk memanfaatkan limbah jagung, sehingga mampu mengatasi masalah pencemaran lingkungan, 2) Memberikan pelatihan kepada santri untuk membuat papan akustik, pakan ternak dan briket, 3) Menghasilkan produk-produk yang berkualitas dan bernilai ekonomis dari bahan limbah tanaman jagung. Metode pelaksanaan kegiatan adalah metode ceramah atau pendekatan persuasif dan praktek langsung bersama para santri. Kegiatan terdiri dari beberapa tahap yaitu: Perencanaan program, tindakan pelaksanaan, observasi dan evaluasi, dan refleksi Tahap perencanaan meliputi survey lokasi kegiatan pengabdian, kondisi pondok pesantren, masyarakat di sekitar dan ketersediaan bahan (limbah jagung), penyusunan program, dan sosialisasi kegiatan. Tahap pelaksanaan meliputi penyuluhan/ceramah, pemutaran video tutorial, dan praktek pembuatan produk serta penyuluhan tentang kewirausahaan. Tahap observasi dan evaluasi meliputi penilaian terhadap proses dan output, dan tahap refleksi dengan meminta tanggapan dari santri tentang manfaat kegiatan yang telah dilaksanakan. Kegiatan ini telah terlaksana dengan baik dan mendapat tanggapan positif dan antusias yang sangat besar dari Pembina dan para santri di pondok pesantren, hal ini ditandai dengan bertambahnya peserta dari target sasaran sebanyak 70 peserta menjadi $80-100$ peserta. Para santri telah berhasil membuat produk papan akustik yang terbuat dari limbah kulit jagung, pakan ternak terbuat dari tongkol jagung yang telah difermentasi serta briket yang terbuat dari
\end{abstract}


tongkol jagung yang diarangkan terlebih dahulu. Untuk membuat produk papan akustik dengan ukuran $25 \mathrm{~cm} \times 25 \mathrm{~cm} \times 1 \mathrm{~cm}$ dibutuhkan $3 \mathrm{~kg}$ kulit jagung kering dan $0,3 \mathrm{~kg}$ lem fox yang telah diencerkan menggunakan air dengan perbandingan 1:10. Dibutuhkan 1,5 kg tongkol jagung 3\% (dari massa tongkol jagung) urea selanjutnya difermentasi selama 21 hari. Sedangkan untuk membuat briket tongkol jagung dibutuhkan $1 \mathrm{~kg}$ tongkol jagung yang telah diarangkan dan $0,1 \mathrm{~kg}$, tepung kanji sebagai perekat.

Kata Kunci: Pesantren, Limbah jagung, Teknologi tepat guna, Papan akustik, Pakan ternak, Briket.

\section{PENDAHULUAN}

$\mathbf{P}$ erkembangan masyarakat dewasa ini menghendaki adanya pembinaan anak didik yang dilaksanakan secara seimbang antara nilai dan sikap, pengetahuan, kecerdasan dan ketrampilan, kemampuan berkomunikasi dengan masyarakat secara luas, serta meningkatkan kesadaran terhadap alam lingkungannya. Asas pendidikan yang demikian itu diharapkan mampu menciptakan atau mempersiapkan masyarakat guna melakukan suatu pekerjaan yang menjadi mata pencahariannya dan berguna bagi masyarakatnya, serta mampu menyesuaikan diri secara konstruktif terhadap perubahan-perubahan yang terjadi di lingkungan sekitarnya.

Untuk memenuhi tuntutan pembinaan dan pengembangan masyarakat berusaha mengerahkan segala sumber dan kemungkinan yang ada agar pendidikan secara keseluruhan mampu mengatasi berbagai problem yang dihadapi masyarakat dan bangsa. Kini masyarakat dan bangsa dihadapkan dengan berbagai masalah dan persoalan yang mendesak, masalah-masalah yang paling menonjol ialah tekanan masalah penduduk, krisis ekonomi, pengangguran, arus urbanisasi dan lainnya. Sementara krisis nilai, terancamnya kepribadian bangsa, dekadensi moral semakin sering terdengar. Dalam upaya mengerahkan segala sumber yang ada dalam bidang pendidikan untuk memecahkan berbagai masalah tersebut, maka ekstensi pondok pesantren akan lebih disorot. Karena masyarakat dan Pemerintah mengharapkan pondok pesantren yang memiliki potensi yang besar dalam bidang pendidikan. 
Seiring dengan laju perkembangan masyarakat maka pendidikan pesantren baik tempat bentuk hingga substansi telah jauh mengalami perubahan. Pesantren tak lagi sesederhana seperti apa yang digambarkan seseorang akan tetapi pesantren dapat mengalami perubahan sesuai dengan pertumbuhan dan perkembangan zaman. Seiring dengan perjalanan waktu pesantren sedikit demi sedikit maju tumbuh dan berkembang sejalan dengan proses pembangunan serta dinamika masyarakatnya. Ini menunjukkan bahwa ada upaya-upaya yang dilakukan pesantren untuk mendinamisir diri sejalan dengan tuntutan dan perubahan masyarakatnya.

Saat ini perkembangan pesantren menunjukkan bahwa beberapa pesantren ada yang tetap berjalan meneruskan segala tradisi yang diwarisi secara turun temurun tanpa perubahan dan inprovisasi yang berarti kecuali sekedar bertahan. Namun ada juga pesantren yang mencoba mencari jalan sendiri dengan harapan mendapatkan hasil yang lebih baik dalam waktu yang singkat. Pesantren semacam ini adalah pesantren yang menyusun kurikulum berdasarkan pemikiran akan kebutuhan santri dan masyarakat sekitarnya.

Dinamika pesantren memang harus diakui mempunyai dampak yang besar contoh semakin dituntut dengan ada teknologi yang canggih pesantrenpun tak ketinggalan zaman untuk selalu mengimbangi dari tiap persoalan-persoalan yang terkait dengan pendidikan maupun sistem di dalam pendidikan itu sendiri mulai dari sisi mengaji ke mengkaji. Itupun merupakan sebuah bukti konkrit di dalam pesantren itu sendiri bahwa mengalami perkembangan dan pertumbuhan. Karena pesantren tak akan pernah mengalami statis selama dari tiap unsur-unsur pesantren tersebut bisa menyikapi dan merespon secara baik apa yang paling aktual.

Pesantren sekarang ini mengalami pergeseran nilai yang luar biasa khususnya berkaitan dengan dunia pekerjaan. Jika dahulu pesantren masih dianggap tabu jika berbicara tentang pekerjaan atau urusan duniawi apalagi sampai mengembangkan kewirausahaan maka sekarang ini pengembangan kewirausahaan di lingkungan pesantren sudah menjadi keniscayaan atau 
kebutuhan apalagi jika hal ini dikaitkan dengan pendidikan pesantren yang mengedepankan kemandirian, kerja keras, disiplin dan jujur.

Perguruan Tinggi sebagai pengemban Tridharma Perguruan Tinggi memiliki tanggungjawab terhadap peningkatan sumber daya manusia melalui transformasi ilmu dan inovasi teknologi hasil-hasil riset pada masyarakat, salah satu diantaranya adalah memberikan pemahaman tentang pengolahan limbah hasil pertanian jagung melalui penerapan teknologi tepat guna. Teknologi tepat guna adalah teknologi yang menggunakan sumber daya yang ada untuk memecahkan masalah yang dihadapi secara berdayaguna dan berhasil guna untuk pelaksanaan tugas sehari-hari menjadi lebih mudah, murah, sederhana dan berdampak polutif seminimal mungkin dibandingkan dengan teknologi arus utama, yang pada umumnya beremisi banyak limbah dan mencemari lingkungan.

Jagung merupakan komoditas pertanian yang strategis di Kabupaten Maros setelah padi, berdasarkan data dari pemerintah daerah kabupaten Maros (BPS, 2014) produksi jagung mencapai 1,5 ton/tahun. Kegiatan panen jagung akan menyisakan limbah berupa batang, tongkol dan kulit jagung. Tanaman jagung memiliki banyak kegunaan. Pada umumnya tanaman jagung dimanfaatkan dalam industri pangan dan pembuatan pakan ternak. Meskipun limbah jagung telah banyak dimanfaatkan sebagai bahan pakan ternak, namun jumlah pemakaiannya tidak sebanding dengan dengan jumlah limbah jagung yang dihasilkan. Jika limbah tersebut tidak ditangani dengan baik maka akan berdampak terhadap terjadinya pencemaran lingkungan.Untuk itu dibutuhkan teknologi yang tepat guna dalam mengolah limbah tanaman jagung agar dapat berdaya guna dan dapat menopang perekonomian di lingkungan pesantren dalam rangka membentuk kemandirian ekonomi.

Pondok pesantren Nahdlatul Ulum kabupaten Maros, terletak tidak jauh dari Balai Penelitian Tanaman Serealia (Balitseral) yang bertugas untuk melaksanakan penelitian tanaman jagung, sorgum, gandum dan serealia menjadi pertimbangan utama untuk mengolah sisa hasil pengolahan khususnya limbah tanaman jagung yang belum dimanfaatkan secara maksimal. 
Mengingat potensi limbah tanaman jagung di sekitar pondok pesantren cukup besar maka perlu dilakukan pendampingan kepada para santri agar dapat mengolah limbah tersebut menjadi produk kreatif yang bernilai ekonomis dengan menggunakan teknologi tepat guna. Misi program pengabdian kepada masyarakat ini adalah menjadikan pondok pesantren sebagai model atau percontohan aplikasi ilmu sains dan teknologi tepat guna bidang pendidikan dan produksi.

Domain krusial dari program pembenahan bidang pendidikan dan produksi adalah meningkatkan pemahaman tentang cara melestarikan alam guna meminimalisir terjadinya pencemaran akibat limbah, pengolahan limbah kulit jagung menjadi dinding akustik yang dapat meredam tingkat kebisingan, pengolahan limbah tongol jagung menjadi pakan ternak yang lebih berkualitas dengan metode fermentasi, pembuatan briket dari limbah tongkol jagung sebagai energi alternatif.

\section{METODE PENELITIAN DAN PELAKSANAAN KEGIATAN}

\section{Strategi Aksi}

Untuk mencapai kondisi yang diharapkan kegiatan pengabdian kepada masyarakat ini dilakukan secara bertahap. Pelaksanaan kegiatan ini mengadopsi langkah-langkah action research yang terdiri dari empat tahapan yaitu: perencanaan, tindakan, observasi dan evaluasi, dan refleksi yaitu dengan cara :

a) Tahap pertama (Prencanaan):

Kegiatan yang dilakukan pada tahap ini meliputi :

1) Melakukan survey lokasi

Tim berkunjung ke lokasi kegiatan untuk memperoleh data-data pendukung kegiatan yaitu identifikasi permasalahan di pondok pesantren, ketersediaan bahan baku (limbah tanaman jagung) di lokasi kegiatan pengabdian kepada masyarakat sekaligus berdikusi dengan pembina pondok pesantren tentang rencana kegiatan pengabdian agar dalam penentuan Jadwal Pelasanaan Kegiatan tidak mengganggu kegiatan lainnya yang telah ada di pondok pesantren. 
2) Penyusunan program

Setelah mengetahui gambaran tentang lokasi kegiatan, tahap selanjutnya adalah melakukan kegiatan diskusi dengan tim pengabdi yang terdiri dari Ketua Tim berasal dari Fakultas Tarbiyah dan keguruan (FTK) Jurusan pendidikan Biologi, dua tim pengabdi lainnya berasal dari Fakultas Sains dan Teknologi terdiri dari 1 orang dari Jurusan Fisika dan satu orang lainnya dari juruan Biologi, tahap ini bertujuan untuk meminta masukan dari berbagai pihak untuk menyusun program berdasarkan permasalahan di lokasi. Adanya variasi latar belakang pendidikan dari tim pengabdi diharapkan dapat memberikan masukan yang bervariasi pula dalam hal pengolahan limbah tanaman jagung yang menjadi krusial dalam kegiatan ini.

3) Berkoordinasi dengan pusat pengabdian kepada masyarakat

Koordinasi dari Tim pengabdian dengan Lembaga Penelitian dan pengabdian kepada Masyarakat (LP2M) UIN Alauddin dilakukan pada saat kegiatan akan dimulai. LP2M bertugas untuk membuat surat tugas kepada tim pengabdi sebagai tanda izin kegiatan pengabdian di lokasi pondok pesantren akan dimulai sesuai dengan jadwal yang telah ditentukan oleh tim.

4) Adanya surat tugas yang telah dikeluarkan dari LP2M menandakan dimulainya tahap dari tahap kegiatan pengabdian. Tahap awal sebelum dilaksanakan tahap tindakan lebih lanjut, dilakukan sosialisasi kegiatan kepada Pembina pondok pesantren yang bertujuan untuk menyampaikan maksud dan tujuan kegiatan, sasaran capaian yang diharapkan dan jadwal pelaksanaan kegiatan.

b) Tahap kedua (Tindakan)

Tindakan dalam kegiatan ini berupa implementasi program yang dilakukan dengan cara pendekatan persuasif yang terdiri dari beberapa tahap. Pada tahap ini diharapkan terbangun komunikasi yang baik dengan pihak mitra dalam hal ini santri di pondok pesantren, adapun tahapan dalam 
kegiatan ini terdiri dari :

5) Penyuluhan I tentang perlunya menjaga kelestarian lingkungan

6) Penyuluhan II tentang aplikasi teknologi tepat guna dalam mengolah limbah pertanian khususnya limbah jagung.

7) Pelatihan atau pendampingan pembuatan :

a) Dinding akustik dari limbah kulit jagung

b) Pakan ternak yang terbuat dari limbah tongol jagung

c) Pembuatan briket dari limbah jagung sebagai energi alternatif

8) Penyuluhan III tentang kewirausahaan dan teknik pemasaran

Dalam upaya mengaplikasikan teknologi tepat guna dalam mengolah limbah jagung, pelaksanaan kegiatan Pengabdian kepada masyarakat ini dilakukan dibagi dalam empat tahap, yang terdiri dari:

1) Pembuatan dinding akustik dari limbah kulit jagung

Bahan baku dalam pembuatan dinding akustik adalah serat alam yang berasal dari kulit jagung, sedangkan material yng digunakan sebagai matrik yaitu polyester yang dicampur dengan MEKPO sebanyak 5\%. Kulit jagung yang sudah dipisahkan dari kotoran dan tanah direndam dalam air selama 3 minggu, dilakukan penyisiran kulit jagung, diperoleh serat kulit jagung dan keringkan serat kulit jagung pada ruang terbuka di bawah sinar matahari, selanjutnya serat kulit jagung direndam dengan $\mathrm{NaOH}(2 \%)$ selama 1 jam, kemudian dibersihkan dengan air mengalir. Tahap selanjutnya serat kulit jagung dikeringkan pada ruang terbuka di bawah sinar matahari, kemudian dilakukan pengujian sifat fisis dari serat kulit jagung meliputi densitas dan kadar air. Selanjutnya serat kulit jagung yang telah dikeringkan kemudian dicacah atau digiling untuk mendapatkan ukuran serat yang lebih kecil. Kemudian limbah kulit jagung yang telah digiling atau diblender dicampurkan dengan perekat polyester kemudian dicetak dengan menggunakan cetakan yang terbuat dari kayu dengan berukuran $25 \mathrm{~cm} \times 25 \mathrm{~cm} \times 1 \mathrm{~cm}$, selanjutnya dikeringan dibawah terik matahari. 
2) Mengolah limbah tongkol jagung sebagai pakan ternak yang berkualitas

Proses fermentasi dalam pembuatan pakan ternak bertujuan menurunkan kadar serat kasar, meningkatkan kecernaan dan sekaligus meningkatkan kadar protein kasar (Tampoebolon, 1997). Penggunaan teknologi amoniasi fermentasi, dapat meningkatkan kandungan protein kasar tongkol jagung dengan menurunkan kandungan serat kasar, serta meningkatkan kecernaan tongkol jagung, sehingga dapat digunakan sebagai alternatif pakan yang baik untuk ternak ruminansia.

Cara pembuatan Amoniasi tongkol jagung dengan menggunakan bahan kimia (urea) adalah sebagai berikut:

1) Alat dan bahan yang diperlukan: Tongkol jagung,Timbangan, mesin penggiling, plastik besar warna hitam, bak air, urea 3\% dari berat tongkol jagung dan Gayung

2) Cara pembuatan amoniasi tongkol jagung menggunakan urea adalah: Timbang tongkol jagung sesuai kebutuhan, setelah itu tongkol jagung di giling, larutkan urea ke dalam air dengan suhu $70^{\circ} \mathrm{C}$. Air digunakan sebanding dengan berat tongkol jagung, untuk mendapatkan bahan kering campuran lebih kurang $60 \%$. Larutan tersebut dicampurkan dengan tongkol jagung yang sudah digiling, setelah dicampur masukan tongkol jagung tersebut ke dalam plastih hitam, kemudian ikat dengan tali dan disimpan dalam keadaan kedap udara selama 14 hari.

3) Setelah 14 hari sebelum digunakan tongkol jagung amoniasi di angin-anginkan dahulu selama satu malam untuk menguapkan sisa amoniak yang tidak terserap dalam tongkol jagung, setelah itu tongkol jagung amoniasi siap untuk digunakan. Pemberian tongkol jagung amoniasi yang dicampur dengan konsentrat dengan perbandingan 1:1. 


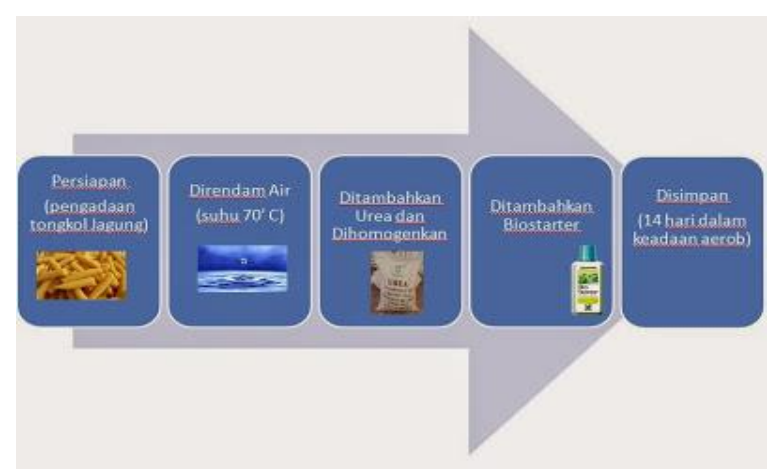

Gambar 1. Proses pembuatan pakan ternak

3) Pembuatan briket dari limbah jagung sebagai energi alternatif

Secara garis besar, briket arang dari tongkol jagung ini disebut briket boiarang, dibuat dengan dirubah bentuk dan ukurannya dengan cara dipress dan memakai campuran perekat. Penggunaan perekat bertujuan agar ikatan antar partikel arang menjadi semakin kuat. Bahan utama untuk pembuatan arang diantaranya adalah tongkol jagung dan untuk perekat kita bisa menggunakan tepung kanji dan tepung sagu. Berikut proses pembuatannya :

1) Bersihkan tongkol Jagung dan pastikan sudah kering.

2) Tongkol jagung yang sudah kering dimasukkan ke kompor pengarangan (reaktor karbonisasi).

3) Tumbuk dan ayak (sortasi/pemilahan) arang tongkol jagung.

4) Campurkan arang yang dihasilkan dari pembakaran tongkol jagung dengan perekat (bisa dengan lem kanji).

5) Siapkan Cetakan Briket (bisa dari pipa paralon).

6) Tongkol jagung dicetak.

7) Pengeringan (bisa dengan menjemur di bawah sinar matahari selama 1-2 hari).

4) Pengemasan

Untuk pengembangan usaha pengolahan limbah tanaman jagung agar layak distribusi ke pasar maka tahap terakhir setelah pembuatan produk papan akustik, pakan ternak dan briket tongkol jagung adalah memberikan penyuluhan tentang proses pengemasan produk. Untuk 
papan akustik dapat dikemas dengan menggunakan kotak yang terbuat dari kayu dengan ukuran $27 \times 27 \times 5 \mathrm{~cm}^{3}$, untuk setiap 1 kemasan terdiri dari empat buah papan akustik. Sedangkan proses pengemasan untuk produk pakan ternak dan briket tongkol jagung menggunakan kemasan plasik yang dikemasan dengan cara divakum atau menggunakan hotpress. Setiap satu kemasan untuk pakan ternak dan briket masing-masing terdiri dari $1 \mathrm{~kg}$.

c) Observasi dan Evaluasi

Observasi dilakukan terhadap proses pengolahan limbah oleh para peserta. Hal-hal yang diobservasi adalah kendala-kendala, kekurangankekurangan, dan kelemahan-kelemahan yang muncul dalam proses pembuatan di lapangan. Sedangkan evaluasi dilakukan terhadap kualitas dan kuantitas produk yang dihasilkan.

d) Refleksi

Refleksi dilakukan terhadap kegiatan yang telah dilaksanakan. Hal ini dilakukan untuk mengetahui kekurangan-kekurangan atau kelebihankelebihan terhadap kegiatan yang telah dilakukan dalam rangka untuk menetapkan rekomendasi terhadap keberlangsungan atau pengembangan kegiatan-kegiatan berikutnya.

\section{Sharing Knowledge}

Tahap selanjutnya dari kegiatan pengabdian kepada masyarakat ini yaitu proses penyebarluasan ilmu pengetahuan melalui kegiatan seminar nasional dan publish pelaporan dalam bentuk jurnal.

\section{HASIL DAN PEMBAHASAN}

Hasil yang dicapai melalui kegiatan pengabdian kepada masyarakat ini dituangkan dalam bentuk hasil kegiatan pada setiap tahap pelaksanaan sebagai berikut: 


\section{A. Hasil Kegiatan}

\section{Perencanaan}

Kegiatan-kegiatan yang dilaksanakan pada tahap perencanaan adalah sebagai berikut:

(1) Melakukan survey awal di Lokasi Kegiatan

Tahap awal kegiatan ini yaitu tim melakukan survey di pondok pesantren Nahdlatul Ulum Kabupaten Maros untuk memperoleh data awal sebagai pendukung kegiatan ini. Dari survey tersebut diperoleh beberapa informasi antara lain jumlah santri terdiri dari 40 santri yang berasal dari berbagai daerah Sulawesi Selatan dan sisanya berasal dari luar Sulawesi Selatan. Target awal peserta kegiatan sebayak 70 santri, namun antusias dari para santri terhadap kegiatan ini terlihat dengan meningkatnya peserta menjadi 90 orang. Informasi lainnya adalah Masyarakat disekitar pondok sebagian besar berprofesi sebagai petani sawah maupun ladang dan peternak. Selain itu diperoleh pula informasi penting lainnya mengenai ketersediaan bahan baku limbah jagung yang cukup melimpah dan belum diolah secara maksimal.

(2) Penyusunan Program dan Presentasi Proposal

Penyusunan program berdasarkan hasil survey dan permasalahan yang ditemukan pada saat observasi lapangan. Diskusi dengan rekan dosen dari berbagai jurusan di tingkat fakultas dilakukan untuk memaksimalkan program kegiatan yang akan dilakukan. Selanjutnya hasil diskusi dituangkan dalam bentuk proposal yang diajukan untuk ikut seleksi dan dipresentasikan oleh Ketua Tim untuk mendapatkan bantuan dana peningkatan mutu pengabdian masyarakat tahun 2016 dari DIKTIS.

(3) Koordinasi dengan LP2M

Koordinasi dengan LP2M dilakukan dalam bentuk pemberian rekomendasi untuk ikut berkompetisi memperoleh bantuan dana peningkatan mutu pengabdian kepada masyarakat tahun 2016 dari DIKTIS. Selanjutnya koordinasi dengan LP2M dilakukan pada saat akan melaksankan kegiatan dalam bentuk memberikan surat tugas kepada tim 
pengabdi (rekomendasi dan surat tugas terlampir).

(4) Sosialisasi kegiatan

Tahap selanjutnya adalah mensosialisasikan rencana program kegiatan pada mitra/stakeholder yaitu Pembina Pondok Pesantren Nahdlatul Ulum Kabupaten Maros. Hasilnya adalah Pembina pondok sangat mengapresiasi kegiatan ini dengan alasan di pondok pesantren belum pernah dilakukan kegiatan pengabdian kepada masyarakat yang berasal dari Perguruan Tinggi dan alasan yang tidak kalah pentingnya adalah keinginan dari para santri untuk meningkatkan pengetahun mereka tentang cara melestarikan alam sebagai upaya meminimalisir terjadinya pencemaran lingkungan disekitar pondok pesantren serta antusias yang sangat besar dari para santri untuk mengetahui dan memahami/pendidikan soft skill bagaimana cara pengolahan limbah jagung yang terdiri dari kulit dan tongkol jagung. limbah tanaman jagung disekitar pondok belum dikelola secara maksimal.

\section{Pelaksanaan Tindakan}

Pelaksanaan kegiatan dilakukan dalam 4 (empat) tahap.

(1) Penyuluhan I dengan tema pelestraian Lingkugan

Tahap pertama yaitu dilakukan dengan cara memberikan penyuluhan dengan tema pentingnya "menjaga kelestarian lingkungan". Kegiatan ini diawali dengan pengarahan sekaligus membuka kegiatan secara resmi oleh bapak Akbar, S.HI, selaku Pembina pondok pesantren. Pada dasarnya Pembina pondok pesantren sangat menyambut baik kehadiran tim pengabdi, mengingat dipondok pesantren tersebut belum pernah diadakan kegiatan pengabdian baik yang diadakan oleh lembaga pencinta lingkungan maupun yang diadakan oleh perguruan tinggi yang ada di Sulawesi selatan, sehingga Pembina pondok pesantren mengharapkan seluruh santri mengikuti dengan serius seluruh rangkaian kegiatan. Acara dilanjutkan dengan penjelasan teknis program dan pemaparan materi oleh Tim dengan tema Pelestarian lingkungan. Hal penting yang disampaikan kepada para santri pada tahap ini adalah memberikan pemahaman tentang lingkungan dan perubahannya 
(kerusakan) akibat ulah manusia, permasalahan keanekaragaman hayati, bencana yang terjadi yang diakibatkan oleh terjadinya pencemaran serta seperti pemanasan global, efek rumah kaca, dll. Metode yang digunakan pada tahap ini yaitu metode persuatif atau memberikan ceramah, agar kegiatan menjadi menarik, tim pengabdi menampilkan video tentang lingkungan sehat dan lingkungan yang telah tercemar. Kegiatan berjalan dengan lancar dan diakhiri dengan tanya jawab.

(2) Penyuluhan II tentang aplikasi teknologi tepat guna dalam mengolah limbah pertanian khususnya limbah jagung

Kegiatan selanjutnya diambil alih oleh tim pengabdi yang dilakukan dengan cara memberikan penyuluhan kedua dengan tema aplikasi teknologi tepat guna dalam mengolah limbah tanaman jagung. Didahului dengan memberikan penjelasan secara tentang teknologi tepat guna (TTG). TTG merupakan jembatan antara teknologi tradisional dan teknologi maju atau dapat pula diartikan sebagai teknologi yang dirancang bagi suatu masyarakat tertentu agar dapat disesuaikan dengan aspek-aspek lingkungan, keetisan, kebudayaan, sosial, politik, dan ekonomi masyarakat yang bersangkutan. Dari tujuan yang dikehendaki, teknologi tepat guna haruslah menerapkan metode yang hemat sumber daya, mudah dirawat, dan berdampak polutif minimalis.

Hasil survey kondosi lokasi menunjukan bahwa hasil panen jagung masyarakat disekitar pondok pesantren melimpah pada saat selesai panen hal ini berdampak terhadap tingginya limbah hasil panen jagung jika limbah tersebut dibiarkan akan berdampak terhadap tercemarnya lingkungan. Pengolahan limbah jagung menjadi produk yang berkualitas dan diharapkan bernilai ekonomis dapat dilakukan dengan pendekan metode teknologi tepat guna dengan pertimbangan ketersedian bahan baku yang melimpah serta proses pengolahan tidak membutuhkan biaya yang besar.

Dalam limbah kulit jagung terdapat selulosa 36,81\%, abu 6,04\%, lignin $15,7 \%$, dan hemiselulosa $27,01 \%$, kandungan tersebut dapat dimanfaatkan sebagai serat alami yang dapat difungsikan sebagai material 
penyerap ataupun peredam suara. Dengan pertimbangan tersebut telah banyak dilakukan penelitian tentang dinding akustik yang berasal dari serat alam. Salah satunya adalah penelitian yang telah dilakukan oleh rahmaniah, 2016 dengan dengan judul pembuatan dan karakterisasi dinding akustik dari limbah kulit jagung. Hasil penelitian tersebut menunjukkan papan akustik dari limbah kulit jagung dengan menggunakan lem fox sebagai perekat dapat menyerap bunyi dengan nilai koefisien absorbsi terbesar $0,22 \mathrm{~cm}^{-1}$, ketebalan papan sebesar $1 \mathrm{~cm}$, sedangkan pada papan dari triplex dengan ketebalan yang sama dihasilkan nilai koefisien absorbsi sebesar $0,12 \mathrm{~cm}^{-1}$.

Selain limbah kulit jagung diperoleh pula limbah lainnya pada saat musim panen yaitu limbah tongkol jagung. Limbah pertanian berupa tongkol jagung sangat melimpah di sekitar lokasi pengabdian, terutama pada saat musim panen. Selama ini limbah tongkol jagung belum dimanfaatkan, hanya di bakar atau hanya dibuang begitu saja dan nantinya akan menjadi sampah yang membusuk. Tongkol jagung merupakan sisa hasil pertanian yang masih memiliki kualitas yang rendah. Tongkol jagung digunakan sebagai bahan konsentrat pada pakan ternak ruminansia. Kandungan serat kasar tinggi, protein dan kecernaan rendah. Oleh karena itu, dalam pemanfaatannya sebagai bahan pakan, tongkol jagung perlu ditingkatkan kualitasnya antara lain dengan teknologi pengolahan amoniasi fermentasi (amofer). Penggunaan tongkol jagung yang telah difermentasi dengan Aspergillus niger sebanyak 50\% dalam konsentrat pada sapi PO yang mendapat pakan basal jerami padi mampu menghasilkan pertambahan bobot hidup harian $(\mathrm{PBBH})$ yang tidak berbeda nyata dengan sapi PO yang diberi pakan konsentrat tanpa tongkol jagung, sehingga penggunaan tongkol jagung dalam konsentrat sebanyak 50\% mampu meningkatkan nilai keuntungan (Anggraeny et al., 2008).

Untuk mengurangi ketergantungan terhadap bahan bakar minyak pemerintah telah menerbitkan Peraturan Presiden Republik Indonesia nomor 5 tahun 2006 tentang kebijakan energi nasional untuk mengembangkan sumber energi alternatif sebagai pengganti bahan bakar minyak. Kebijakan 
tersebut menekankan pada sumber daya yang dapat diperbaharui sebagai altenatif pengganti bahan bakar minyak. Bahan bakar alternatif sebagai pengganti bahan bakar minyak dapat memanfaatkan energi terbarukan seperti biomassa. Biomassa adalah salah satu energi alternative yang berpotensi sangat besar di Indonesia. Selain dapat dimanafaatkan sebagai pakan ternak tongkol jagung dapat pula dioleh menjadi biomasssa yang berfungsi sebagi energi alternatif dalam bentuk briket. hal ini dikarenakan bahwa briket yang berasal dari pengolahan limbah tongkol jagung mengahasilkan nilai kalor sebesar 2912 kal/g - 6757kal/g (Haris Lukum, dkk).

Berdasarkan hasil penelitian tersebut tim pengabdi mencoba mengaplikasilan metode tepat guna di pondok pesantren Nahdlul Ulum untuk pembuatan papan akustik, pakan ternak dan briket, diamana ketiga produk tersebut berasal dari pengolahan limbah hasil pertanaian jagung.

Selain penjelasan tentang ketersedian, teori yang mendasari sehingga limbah tersebut dapat diolah menjadi produk yang lebih bermanfaat, diperlihatkan pula beberapa video tutorial terkait dengan pengolahan limbah jagung hal ini bertujuan agar para santri lebih memperhatikan dan lebih tertarik dengan apa yang tim telah sampaikan.

Di akhir sesi, tim meminta kepada santri untuk membentuk 6 kelompok yang terdiri dari 10-11 orang. Pembagian kelompok ini dilakukan untuk persiapan kegiatan berikutnya yaitu kegiatan pelatihan atau pendampingan praktek pembuatan papan akustik, pembuatan pakan ternak dan pembuatan briket.

(3) Pelatihan atau pendampingan pembuatan

Tahap selanjutnya merupakan kegiatan pendampingan dari setiap kelompok yang telah dibagi sebelumnya untuk pembuatan produk pengolahan limbah jagung. Kegiatan ini merupakan rangkain dari kegiatan sebelumnya, dimana pada kegiatan sebelumnya telah diberikan penyuluhan/penjelasan yang juga disertai dengan penyajian pemutaran video tentang proses pengolahan limbah jagung menjadi produk yang 
bernilai eknomis terdiri dari pembuatan papan akustik dari kulit jagung yang telah dikeringkan, pembuatan pakan ternak yang terbuat dari tongkol jagung yang telah difermentasi dan yang terakhir adalah pembuatan briket terbuat dari tongkol jagung yang telah terlebih dahulu dibuat jadi arang. Tahap akhir pada kegiatan ini adalah masing-masing kelompok berkreasi membuat produk dari limbah jagung. Kelompok yang menampilkan kreasi yang baik mendapatkan rewards dari tim pengabdi.

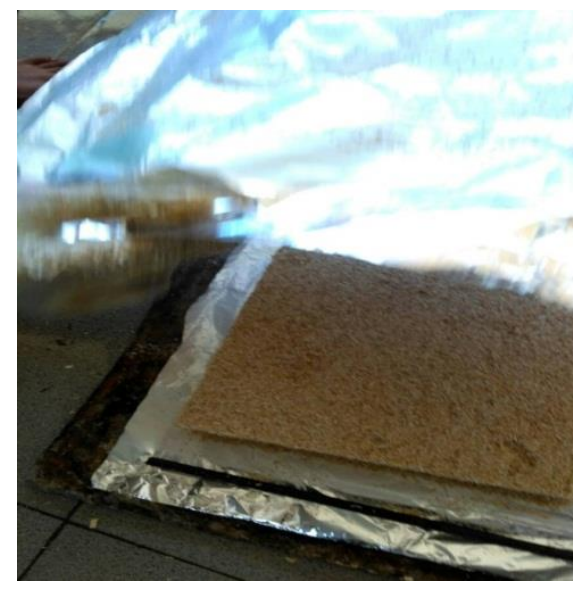

$\mathrm{a}$

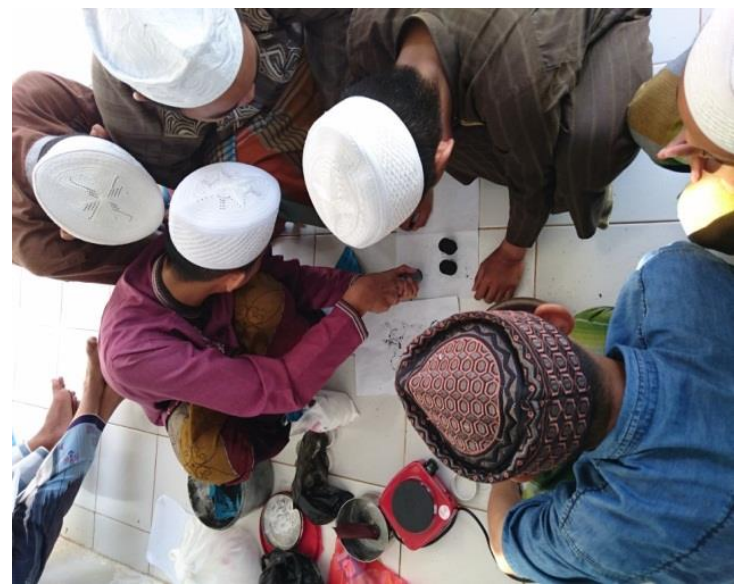

b

Gambar 2. Produk yang dibuat oleh para santri (a) Papan akustik, (b) Briket

(4) Penyuluhan III tentang kewirausahaan dan teknik pemasaran

Tahap pelaksanaan tindakan dalam kegiatan ini diakhiri dengan kegiatan penyuluhan tentang upaya meningkatkan minat kewirausahaan dikalangan santri dan teknik pemasaran baik yang disampaikan oleh narasumber tim pengabdi. Diharapkan para santri selain memperoleh pengetahuan tentang pengolahan limbah jagung dengan pemanfaatan teknologi tepat guna diharapkan pula para santri mendapatkan nilai ekonomi dari produk yang telah dibuat, mengingat letak pondok pesantren tidak jauh dari pasar tradisional menjadi keuntungan tersendiri dari sisi lokasi pemasaran produk.

Sesi terakhir sebelum penutupan oleh Pembina pondok pesanten ust. Akbar, S.HI, terlebih dahulu dilakukan penyerahan rewards kepada para 
kelompok yang telah menghasilkan produk olahan berdasarkan penilaian kualitas dan kuantitas produk yang telah hasilkan. Selain itu tim pengabdi juga meminta tanggapan dari para peserta baik lisan maupun tertulis dari para peserta tentang kekurangan dan kelebihan dari kegiatan ini sebagai rekomendasi untuk kegiatan selanjutnya.

\section{Observasi dan Evaluasi}

Kegiatan observasi dilakukan terhadap proses pembuatan berbagai produk dari limbah jagung. Sedangkan tahap evaluasi dilakukan terhadap kualitas dan kuantitas produk yang dihasilkan. Evaluasi juga dilakukan terhadap para peserta dengan cara melihat apakah peserta termotivasi setelah mengikuti kegiatan pengabdian ini. Produk yang dihasilkan dalam kegiatan ini adalah papan akustik, pakan ternak dan briket. Kuantitas dilihat dari banyaknya produk yang dihasilkan sedangkan kualitas dilihat dari nilai seni dan kekuatan produk yang dihasilkan.

Objek yang diobservasi meliputi kendala-kendala, kekurangan, dan kelemahan yang dialami saat dalam proses pengolahan limbah jagung. Hal-hal yang menjadi kendala saat pembuatan papan akustik adalah proses penekanan dilakukan secara manual karena tidak tersedia alat press hal ini menyebabkan produk yang dihasilkan dari sisi kekuatan kurang maksimal. Untuk produk kedua yakni pembuatan pakan ternak tidak ditemukan kendala yang berarti karena semua tahap dapat dilakukan secara maksimal. Sedangkan untuk produk yang terakhir yakni briket tongkol jagung masalah yang dihadapi adalah briket yang dihasilkan masih memiliki kandungan air cukup tinggi sehingga masih harus dijemur dibawah terik matahari selama kurang lebih 1 hari, namun kondisi pada saat kegiatan sudah mulai musim hujan.

Tahap evaluasi juga dilakukan melalui membagikan kuesioner sederhana kepada para peserta untuk mengetahui apakah ada motivasi/perubahan setelah mengikuti kegiatan. Hasilnya adalah produk yang dihasilkan sudah baik meskipun menggunakan alat sederhana. Untuk mendapatkan hasil yang lebih baik lagi, perlu didukung oleh teknologi yang canggih. Sedangkan hasil kuesioner menunjukkan bahwa pada umumnya peserta sangat termotivasi dengan kegiatan ini. 


\section{Refleksi}

Kegiatan refleksi dilakukan bertujuan untuk mengetahui kekurangan atau kelebihan dari rangkaian kegiatan pengabdian yang telah dilakukan. Proses refleksi dilakukan dengan cara meminta tanggapan atau saran dari pihak-pihak terkait, baik dengan cara lisan maupun tulisan. Hasil kegiatan refleksi menujukkan bahwa pembina pondok pesantren maupun para peserta dalam hal ini para santri termotivasi dan merasa puas dengan adanya kegiatan ini dan berharap ada tindak lanjut atau kegiatan serupa seperti yang piha pondok menyarakankan melaksanakan kegiatan selanjutnya dengan memanfaatkan limbah plastik yang ada lingkungan pondok pesantren Nahdlatul Ulum di Kabupaten Maros.

\section{B. Pembahasan}

Kegiatan pengabdian kepada masyarakat dengan tema pelestraian alam dengan aplikasi teknologi tepat guna dalam memanfaatkan limbah jagung untuk menghasilan produk yang bernilai ekonomis di pondok pesantren Nahdlatul Ulum Kabupaten Maros telah berlangsung dengan baik dan lancar. Hal ini nampak dari antusias yang sangat tinggi dari para peserta dimulai dari awal kegiatan sampai dengan berakhirnya seluruh tahapan kegiatan dibuktikan dengan meningkatnya para peserta dari target awal 70 santri meningkat menjadi 80-90 santri. Meningkatnya jumlah peserta menjadi salah satu indikasi bahwa para peserta menyambut antusias dan positif kegiatan yang telah dilakukan.

Materi yang telah diberikan pada saat penyuluhan diserapkan dengan sangat baik, hal ini dibuktikan dengan melihat ketelatenan para peserta yang dapat mengaplikasikan secara langsung cara membuat produk dari limbah tanaman jagung. Bersama dengan kelompok masing-masing peserta mengasilkan produk papan akustik, pakan ternak dan briket tongkol jagung. Untuk membuat produk papan akustik dengan ukuran $25 \mathrm{~cm} \times 25 \mathrm{~cm} \times 1 \mathrm{~cm}$ dibutuhkan $3 \mathrm{~kg}$ kulit jagung kering dan $0,3 \mathrm{~kg}$ lem fox yang telah diencerkan menggunakan air dengan perbandingan 1:10. Dibutuhkan 1,5 kg tongkol jagung 3\% (dari massa tongkol jagung) urea selanjutnya difermentasi selama 21 hari. Sedangkan untuk membuat briket tongkol jagung dibutuhkan $1 \mathrm{~kg}$ tongkol jagung yang telah diarangkan dan 
0,1 kg, tepung kanji sebagai perekat.

Kuisioner sederhana yang telah dibuat dengan tujuan untuk evaluasi kegiatan pengabdian ini dibagikan pada hari terakhir pelaksanaan program sebanyak 70 kuesioner diperoleh hasil sebagai berikut:

1. Seluruh peserta $(100 \%)$ berpendapat bahwa kegiatan pengabdian masyarakat ini sangat menarik. Hal ini terbukti dengan keseriusan peserta mengikuti setiap sesi tahapan dalam program ini.

2. Seluruh peserta (100\%) berpendapat sangat termotivasi setelah mengikuti kegiatan ini.

3. Sebanyak $100 \%$ peserta mengatakan bahwa materi yang diberikan/topik pengabdian masyarakat ini sangat sesuai dengan kebutuhan mereka.

\section{PENUTUP}

\section{Kesimpulan}

Kesimpulan sementara dari hasil yang dicapai melalui kegiatan ini, sebagai berikut:

1. Kegiatan pengabdian kepada masyarakat dengan tema pelestarian lingkungan dan Penyuluhan apliasi teknologi tepat guna untuk pengolahan limbah tanaman jagung telah terlaksana dengan baik dan mendapat sambutan positif dari pembina dan para santri di Pondok Pesantren Nahdlatul Ulum Kabupaten Maros.

2. Para santri telah berhasil membuat produk papan komposit yang terbuat dari limbah kulit jagung, pakan ternak terbuat dari limbah tongkol jagung yang telah difermentasi dan produk briket yang terbuat dari limbah tongkol jagung yang telah dikeringkan dan diarangkan.

3. Untuk membuat produk papan akustik dengan ukuran $25 \mathrm{~cm} \times 25 \mathrm{~cm} \times 1$ cm dibutuhkan $3 \mathrm{~kg}$ kulit jagung kering dan $0,3 \mathrm{~kg}$ lem fox yang telah diencerkan menggunakan air dengan perbandingan 1:10. Dibutuhkan 1,5 kg tongkol jagung 3\% (dari massa tongkol jagung) urea selanjutnya difermentasi selama 21 hari. Sedangkan untuk membuat briket tongkol 
jagung dibutuhkan $1 \mathrm{~kg}$ tongkol jagung yang telah diarangkan dan $0,1 \mathrm{~kg}$, tepung kanji sebagai perekat.

4. Hasil observasi dan evaluasi selama kegiatan berlangsung disimpulkan bahwa untuk memperoleh hasil pengolahan limbah jagung menjadi sebuah produk papan akustik yang berkualitas dibutuhkan teknologi yang canggih (alat press), sedangkan untuk mengolah limbah tongkol jagung menjadi pakan ternak dan briket telah dibuat dengan peralatan yang sederhana dengan kualitas produk dihasilkan cukup maksimal.

\section{DAFTAR RUJUKAN}

Anggreny, Y.N., U. Umiyasih, And D. Pamungkas. 2005. Pengaruh suplementasi multi nutrien terhadap performans sapi potong yang memperoleh pakan basal jerami jagung. Prosiding Seminar Nasional Teknologi Peternakan dan Veteriner

Anggreny, Y.N., U. Umiyasih, And N.H. Krishna. 2006. Potensi limbah jagung siap rilis sebagai sumber hijauan sapi potong. Prosiding Lokakarya Nasional Jejaring Pengembangan Sistem Integrasi Jagung-Sapi

Azizah, N., 2006. Variasi Konsentrasi Perekat dan Tekanan Kempa Terhadap Sifat Fisika -Kimia Briket Arang dari Kulit Kayu Suren (Toona sureni Merr.). Skripsi S1 Fakultas Kehutanan Universitas Gadjah Mada. Yogyakarta (Tidak dipublikasikan).

Farina, A, Anna Torelli. 2000. Measurement of the sound absorption coefficient of materials with a new sound intensity technique (jurnal universitas Parma). Italy.

Halliday, D dan Robert Resnick. 1996. Fisika Jilid I (terjemahan Pantur Silaban). Jakarta . Erlangga.

Kantor Deputi Menegristek Bidang Pendayagunaan dan Pemasyarakatan Ilmu Pengetahuan dan Teknologi. 2001. Tanaman Perkebunan.

Neithalath, N. Jason Weiss, Jan Olek. 2004. Improving the acoustic absorption of enhanced Porosity concrete with fiber reinforcement (jurnal universitas Purdue). USA.

Ningsih, Eva Rahayu. 2012. Uji Kinerja Digester pada Proses Pulping Kulit Jagung dengan Variabel Suhu dan Waktu Pemasakan. Semarang: Universitas Diponegoro Press. 
136 _ Jurnal Teknosains, Volume 12, Nomor 2, Juli-Desember 2018, hlm. 116 - 136

Rahmaniah, 2016. Pembuatan dan karakterisasi papan peredam suara dari limbah kulit jagung, Makassar (belum dipublish)

Schwartz,M.M. 1984. Composite Materials Handbook. New York: McGraw-

Soejono, M. R. Utomo dan S. Piuyono. S.B. 1985. Pengaruh perlakuan alkali terhadap kecernaan in vitro bagasse. N.K.wardhani(Editors). Pros. Seminar Pemanfaatan Limbah Tebu untuk Pakan Ternak. Puslitbang Peternakan, Bogor. Him: 144-147.

Van Vlack, LH. 1994. Ilmu dan Teknologi Bahan. Edisi Kelima. Terjemahan Japrie, S. Jakarta: Erlangga. 